Vol. 15 (2006): 268-279.

\title{
Effect of concentrate feeding strategy on the performance of dairy cows fed total mixed rations
}

\author{
Hannele Khalili, Päivi Mäntysaari, Juha Sariola and Reima Kangasniemi \\ MTT Agrifood Research Finland, Animal Production Research, FI-31600 Jokioinen, Finland, \\ e-mail:hannele.khalili@mtt.fi
}

\begin{abstract}
Little information is available concerning the effects of offering additional concentrates with total mixed ration (TMR) on milk production. The aim of the present study was to compare TMR representing simplified feeding (TMR1) with TMR combined with a decreasing amount of additional concentrate (TMR2C). Finnish Ayrshire cows (39) were housed in a loose housing barn. TMR1 consisted of a mixed ration of grass silage (0.49) and concentrates (0.51). In TMR2C, the same grass silage and concentrate were mixed in a ratio of 55:45. In TMR2C, cows were offered additional concentrates from automatic feeders differing in composition from the concentrate in TMR1 [6.5 $\mathrm{kg} \mathrm{d}^{-1}$ (first 100 days, Phase 1), $3.0 \mathrm{~kg} \mathrm{~d}^{-1}$ (subsequent 50 days, Phase 2) and no concentrate thereafter (Phase 3)]. During the whole experiment (224 days), total consumption of concentrates per cow averaged $2426 \mathrm{~kg}$ dry matter (TMR1) and $2414 \mathrm{~kg}$ dry matter (TMR2C). There were no significant differences in mean total dry matter, metabolizable energy, crude protein or absorbed amino acid intakes. During Phase 2, total intake of all cows fed TMR2C was one kg lower $(\mathrm{P}=0.10)$ than for cows fed TMR1. This was due to differences in total feed intake of multiparous cows. Average yields $\left(\mathrm{kg} \mathrm{d}^{-1}\right)$ of milk, energy corrected milk, protein, fat and lactose were not significantly different between diets. During Phase 2, primiparous cows tended to produce more energy corrected milk on TMR2C than on TMR1. The results showed that both TMR1 and TMR2C were equal feeding strategies for early lactating cows and cows did not benefit from greater concentrate consumption in early stage of lactation when total consumption of concentrates was similar.
\end{abstract}

Key words: dairy cows, concentrates, grass silage, total mixed ration, milk yield, feed intake

\section{Introduction}

During the EU membership since 1995 the number of Finnish farms has fallen, but the aver- age size has increased (Niemi and Ahlstedt 2003). Considering the housing of cows, loose housing is currently often the housing type used in Finland in production units of 50-60 cows or more. Mixing concentrates and silage in a total mixed 
Vol. 15 (2006): 268-279.

ration (TMR) or feeding silage and concentrates separately are both commonly used feeding strategies on dairy farms. In free stall barns, separate concentrate feeding has been accomplished using automatic computerised concentrate feeders (Maltz et al. 1992, Yan et al. 1998, Yrjänen et al. 2003).

In the case of TMR feeding the farm manager decides whether to use one TMR for the whole milking herd or to prepare multiple TMRs (having e.g. high and medium nutrient concentrations) for several groups of cows. In Finland, multiple TMRs and grouping of cows are difficult because of the relatively small herd sizes on farms. Therefore, one TMR for all milking cows would be a practical feeding strategy. Recently, Mäntysaari et al. (2004) reported that feeding fixed or decreasing proportions of concentrates in the TMR to primiparous cows during lactation had no effect on milk production. Thus, one TMR was suitable for primiparous cows due to the fairly even lactation curve with addition of energy for growth at the end of lactation. The circumstances might be less optimal for multiparous cows concerning the use of only one TMR in feeding because those cows produce more milk in early lactation and they have a different lactation curve (a clear peak) and energy partitioning compared to primiparous cows.

Maltz et al. (1992) concluded that computerised dispensing of concentrates can economize on the consumption of concentrates when grouping, and feeding different TMRs is not possible especially in the case of small herds. It is also possible to combine separate concentrate feeding and TMR feeding strategies so that, in addition to TMR, concentrates are fed from automatic feeders. This combination allows to provide several specialised diets without preparing several TMRs and, secondly, more expensive supplementary concentrates could be fed from automatic feeders and cheaper grain-based concentrates could be used in the TMR. Feeding a TMR with a lower energy concentration in combination with additional meals of concentrates during milking should be a suitable feeding strategy with an automatic milking system. Extra concentrates should encourage cow movement to the milking robot.
There is little information available concerning the effects of offering additional concentrates with TMR feeding on milk production. The hypothesis was that cows will increase total milk production when a greater amount of concentrates is allocated in early lactation compared to simplified concentrate feeding. Thus the objective of the present study was to quantify the differences in the feed intake and milk production of dairy cows fed either sole TMR (fixed proportion of concentrate 0.51) representing simplified feeding or TMR (fixed proportion of concentrate 0.45 ) combined with a decreasing amount of additional adjustable concentrate. The second feeding strategy allowed feeding according to milk yield/stage of lactation without the need to group the cows and to prepare several different TMRs. In addition, this study provides further knowledge about simplified feeding based on the use of only one TMR for primiparous and multiparous cows in early and mid-lactation.

\section{Material and methods}

\section{Animals and experimental design}

The experiment was carried out during the first 32 weeks of lactation after parturition with 39 Finnish Ayrshire cows, 15 of which were primiparous. The average live weights of the cows were $582 \mathrm{~kg}$ $\pm 14.0 \mathrm{~kg}$ (primiparous) and $674 \mathrm{~kg} \pm 22.5 \mathrm{~kg}$ (multiparous) after parturition. Animals were housed in a free stall in cubicles with two compartments. The experiment was conducted according to a continuous randomised design. Cows were divided into blocks according to calving date and parturition, and were randomly allocated to two treatments. The experimental treatments were: 1$)$ feeding TMR1 diet ad libitum (8 primiparous and 11 multiparous cows) or 2) feeding TMR2C diet (7 primiparous and 13 multiparous cows). The TMR1 was prepared to contain $0.51 \mathrm{~g} \mathrm{~kg}^{-1}$ of concentrate and $0.49 \mathrm{~g} \mathrm{~kg}^{-1}$ of silage on a dry matter (DM) basis (TMR1). In TMR2C, TMR2 contained $0.45 \mathrm{~g}$ $\mathrm{kg}^{-1}$ of concentrate and $0.55 \mathrm{~g} \mathrm{~kg}^{-1}$ of silage and 
was supplemented with additional concentrate. The total daily amount of additional concentrate (on fresh weight basis) offered per cow was $6.5 \mathrm{~kg}$ on days 1-100 (Phase 1) for multiparous and 5.5 $\mathrm{kg}$ for primiparous cows, on days 101-150 (Phase 2) $3.0 \mathrm{~kg}$ for multiparous and $2.5 \mathrm{~kg}$ for primiparous cows. On Phase 3 (days 151-224) only TMR2 without additional concentrate was given.

\section{Feeds and feeders}

The concentrate in TMR 1 and TMR2 consisted of (g kg-1 dry matter) barley (606), rapeseed cake (270), molassed sugar beet pulp (100) and minerals (24, Suomen Rehu Ltd., Helsinki, Finland, containing $\left(\mathrm{g} \mathrm{kg}^{-1}\right)$ calcium (210), phosphorus (2), magnesium (100), sodium (100), selenium (0.02), vitamin A (130000 iu kg-1), vitamin D (81000 iu $\left.\mathrm{kg}^{-1}\right)$ and vitamin $\mathrm{E}\left(470 \mathrm{mg} \mathrm{kg}^{-1}\right)$ ). Silages were prepared from the first cut of swards consisting predominantly of timothy (Phleum pratense) and meadow fescue (Festuca pratensis) ensiled with a formic acid-based additive ('AIV II', Kemira Agro Ltd., Helsinki, Finland) at a rate of $51 \mathrm{t}^{-1}$ grass. The additional concentrate in the TMR2C diet consisted $\left(\mathrm{g} \mathrm{kg}^{-1} \mathrm{DM}\right)$ of barley (404), rapeseed cake (182), wheat (108), molassed sugar beet pulp (103), molasses (51), soybean cake (56), wheat bran (48), vegetable oil (19), calcium carbonate (18), salt (6), magnesium oxide (3) and premix (2) (Suomen Rehu Ltd., Helsinki, Finland). The chemical composition and contents of metabolizable energy (ME) and amino acids absorbed from the small intestine (AAT) were very similar in the additional concentrate compared to the concentrate in TMR1 and TMR2 (Table 1).

The cows carried collars around their necks with transponders for identification at the feeders and in the milking parlour. Each cow had an individual feeding place with access to TMR1 or TMR2 through computerised feeding gates (RIC access doors, Insentec B.V., Marknesse, The Netherlands). Total mixed ration feedings were carried out by robotic feeding (Pellonpaja Ltd., Ylihärmä, Finland). Computerised feeding robots offered TMR1 and TMR2 once a day, starting at 1245 hours, ensuring proportionate refusals of about 0.05 . On TMR2C, additional concentrates were offered in equal total amounts from computerised concentrate feeders (Pellonpaja Ltd., Ylihärmä, Finland) during four eating periods starting at 0400, 1000, 1330 and 1900 hours.

\section{Measurements, sampling and analysis}

Silage samples were analysed for DM (determined at $105^{\circ} \mathrm{C}$ for $20 \mathrm{~h}$ ) at the beginning of the experiment and twice a week thereafter for preparation of TMR 1 and TMR2. The amount of TMR offered was recorded automatically each day and TMR intakes were measured by recording the orts with an accuracy of $0.5 \mathrm{~kg}$ (fresh weight). Intakes of additional concentrates (TMR2C) were recorded automatically each day. Concentrate samples were collected weekly and a composite sample over four weeks was sent for chemical analysis. Silage samples were collected twice a week and a composite sample over two weeks was sent for the determination of fermentation quality and chemical composition. $\mathrm{pH}$ was determined for each sample. Silage samples were stored at $-20^{\circ} \mathrm{C}$. Silage DM was corrected for volatile losses according to Huida et al. (1986). Feed samples were analysed for organic matter $(\mathrm{OM})$, crude protein $(\mathrm{CP})$ and neutral detergent fibre (NDF), and silage fermentation characteristics were performed using standard procedures previously described by Ahvenjärvi et al. (2000). Concentrate samples were also analysed for ether extract after acid ( $\mathrm{HCl}$ ) hydrolysis (AOAC 1990) and starch (McCleary et al. 1994).

Cows were milked twice a day (0630 and 1600 hours) in a $2 \times 6$ autotandem milking parlour and milk yield was automatically recorded for each milking. Milk samples were taken twice a month over two consecutive milkings. All samples were analysed for fat, protein and lactose by an infra-red analyser. Concentrations in milk were calculated as a weighted mean according to milk yield. Milk samples taken once a month from seven cows per treatment (= every other sampling time) were analysed for urea (McCullough 1967). Live weight of each cow was recorded automatically after each 
Vol. 15 (2006): 268-279.

milking using a computerised walk-through weighing station (Insentec B.V., Marknesse, The Netherlands). Cows were body condition-scored (BCS) at the beginning of the experiment and twice a month thereafter on a scale of 1 to 5 according to Lowman et al. (1976).

\section{Calculations and statistical analyses}

Silage D value (g digestible $\mathrm{OM} \mathrm{kg}^{-1} \mathrm{DM}$ ) was determined according to in vitro digestibility of organic matter (cellulase method, a modification of the method described by Nousiainen et al. 2003). Metabolizable energy and AAT contents of silage were calculated according to Finnish feed tables (MTT 2004). The nutritive value (ME, AAT) of the concentrates was calculated according to chemical analyses as described in the Finnish feed tables. The nutritive values of TMR 1 and TMR2 were calculated based on proportions of concentrates and silages. Energy corrected milk (ECM) values were calculated according to MTT (2004). Milk energy content, ME requirements for maintenance and live weight change were calculated according to MTT (2004). Weekly average live weights and live weight changes were used in calculations. The apparent efficiency of transferring energy into milk $\left(\mathrm{k}_{1}\right)$ was estimated including the effects of live weight change [milk energy / (ME intake - ME requirement for maintenance - ME for live weight change)]. Silage DM intake index was calculated using the approach described by Huhtanen et al. (2002).

Results were calculated for all cows $(\mathrm{n}=39)$ as well as for primiparous $(\mathrm{n}=15)$ and multiparous $(n=24)$ cows. For intake and milk production data the weekly means were used for statistical analysis (repeated measurements, MIXED procedure of SAS, Littell et al. 1996). The variance component estimation method was the restricted maximum likelihood method (REML) and the type of within subject covariance matrix was first-order autoregressive $[\mathrm{AR}(1)]$. The model used was:

$$
\begin{aligned}
\mathrm{y}_{\mathrm{ijklmn}}= & \mu+\mathrm{FS}_{\mathrm{i}}+\mathrm{b}_{\mathrm{I}} \mathrm{I}_{\mathrm{j}}+\mathrm{P}_{\mathrm{k}}+\mathrm{S}_{\mathrm{ijkl}}+\mathrm{W}_{\mathrm{m}}+ \\
& \left(\mathrm{W}^{*} \mathrm{FS}\right)_{\mathrm{mi}}+\mathrm{e}_{\mathrm{ijklm}}
\end{aligned}
$$

where $\mathrm{FS}_{\mathrm{i}}$ represents feeding strategy (TMR1 or TMR2C), $b_{I}$ is the linear effect of pedigree index $\left(\mathrm{I}_{1}\right)$ of the cow appropriate for milk yield, fat or protein content or yield, $\mathrm{P}_{\mathrm{k}}$ is parity, $\mathrm{S}_{\mathrm{ijkl}}$ is the random effect of experimental cow and $\mathrm{W}_{\mathrm{m}}$ the week of lactation. Biweekly BCSs were also analysed using the model without the effect of $\mathrm{b}_{\mathrm{I}} \mathrm{I}_{1}$ and with the exception that $\mathrm{W}_{\mathrm{m}}$ represents a two-week period. Interaction effects between feeding strategy and week of lactation were analysed (shape of lactation curve) and interaction effect was significant $(\mathrm{P}<0.05)$ only for milk fat content (all cows and multiparous). The differences between feeding strategies (TMR1 vs. TMR2C) are presented in the tables.

\section{Results}

Chemical composition and calculated ME and AAT content of experimental feeds and TMRs are presented in Table 1. Silage DM content varied between 226 and $278 \mathrm{~g} \mathrm{~kg}^{-1}$ fresh weight and CP concentrations varied between 142 and $154 \mathrm{~g} \mathrm{~kg}^{-1} \mathrm{DM}$. Silage had a mean $\mathrm{pH}$ value of 3.97 and (on a DM basis $\mathrm{g} \mathrm{kg}^{-1}$ ) a low mean content of water-soluble carbohydrates (57), lactic acid (73), acetic acid (22), propionic acid (0.7) and butyric acid (0.2). Silage average ammonia $\mathrm{N}$ and soluble $\mathrm{N}$ concentrations were 73 and $571 \mathrm{~g} \mathrm{~kg}^{-1}$ total $\mathrm{N}$, respectively. Those numbers indicated that grass silage was of good quality in terms of fermentation parameters and digestibility (D value $706 \mathrm{~g} \mathrm{~kg}^{-1} \mathrm{DM}$ ) and thus the calculated silage DM intake index was 99.1 of 100 which showed good intake potential. The CP and ME contents of TMR1 and TMR2 were very similar. When TMR was based on a mixture of good quality grass silage and concentrate, the increased proportion of concentrate from 450 to $510 \mathrm{~g} \mathrm{~kg}^{-1}$ DM had only a minor effect on the feeding values between TMR1 and TMR2.

There were no significant differences $(\mathrm{P}>$ 0.05) in mean total DM, ME, CP or AAT intakes of all, primiparous and multiparous cows between treatments (Table 2). Considering the average total 
Khalili, H. et al. Offering additional concentrates with total mixed rations to dairy cows

Table 1. Chemical composition of experimental feeds and total mixed rations (TMR).

\begin{tabular}{lccccc}
\hline & Silage & $\begin{array}{c}\text { Concentrate } \\
\text { in TMR }\end{array}$ & $\begin{array}{c}\text { TMR } \\
1\end{array}$ & $\begin{array}{c}\text { TMR } \\
2\end{array}$ & $\begin{array}{c}\text { Commercial } \\
\text { Concentrate }\end{array}$ \\
\hline Dry matter (DM), g kg-1 fresh feed & $252 \pm 26$ & $883 \pm 6$ & $396 \pm 34$ & $372 \pm 31$ & $874 \pm 5$ \\
Organic matter, g kg-1 DM & $925 \pm 6$ & $932 \pm 4$ & $929 \pm 3$ & $929 \pm 4$ & $929 \pm 3$ \\
Crude protein, g kg-1 DM & $148 \pm 6$ & $191 \pm 7$ & $170 \pm 4$ & $168 \pm 4$ & $197 \pm 4$ \\
Neutral detergent fibre, g kg ${ }^{-1} \mathrm{DM}$ & $512 \pm 44$ & $227 \pm 16$ & $369 \pm 21$ & $387 \pm 23$ & $209 \pm 9$ \\
Starch, g kg-1 DM & $\#$ & $352 \pm 33$ & $184 \pm 17$ & $162 \pm 14$ & $334 \pm 16$ \\
Crude fat, g kg & & $53 \pm 5$ & $47 \pm 1$ & $46 \pm 2$ & $59 \pm 6$ \\
Amino acids absorbed in small intestine, & $86 \pm 2$ & $116 \pm 1$ & $101 \pm 1$ & $100 \pm 1$ & $114 \pm 1$ \\
g kg-1 DM $^{-1}$ Metabolizable energy, MJ kg-1 DM & $11.3 \pm 0.3$ & $12.5 \pm 0.1$ & $11.9 \pm 0.1$ & $11.8 \pm 0.1$ & $13.0 \pm 0.1$ \\
\hline
\end{tabular}

\# Not determined

Table 2. Mean treatment effects on average feed intake.

\begin{tabular}{|c|c|c|c|c|c|c|c|c|c|}
\hline & \multicolumn{2}{|c|}{ All cows } & \multirow[b]{2}{*}{ SEM } & \multicolumn{2}{|c|}{ Primiparous cows } & \multicolumn{3}{|c|}{ Multiparous cows } & \multirow[b]{2}{*}{ SEM } \\
\hline & TMR1 & TMR2C & & TMR1 & TMR2C & SEM & TMR1 & TMR2C & \\
\hline \multicolumn{10}{|l|}{ Dry matter intake, $\mathrm{kg} \mathrm{d}^{-1}$} \\
\hline Total mixed ration & 21.2 & 18.4 & 0.38 & 18.7 & 16.8 & 0.46 & 23.6 & 20.1 & 0.55 \\
\hline Additional concentrates & ng & 2.4 & & ng & 2.0 & & ng & 2.7 & \\
\hline Total & 21.2 & 20.8 & 0.35 & 18.7 & 18.8 & 0.42 & 23.6 & 22.8 & 0.52 \\
\hline Metabolizable energy, $\mathrm{MJ} \mathrm{d}^{-1}$ & 252 & 249 & 4.2 & 222 & 225 & 4.9 & 281 & 271 & 6.3 \\
\hline Crude protein, $\mathrm{g} \mathrm{d}^{-1}$ & 3615 & 3577 & 58.1 & 3189 & 3232 & 71.8 & 4028 & 3917 & 86.1 \\
\hline $\begin{array}{l}\text { Amino acids absorbed in small } \\
\text { intestine, } \mathrm{g} \mathrm{d}^{-1}\end{array}$ & 2142 & 2103 & 35.1 & 1892 & 1902 & 42.0 & 2384 & 2301 & 52.5 \\
\hline
\end{tabular}

TMR1 = Total mixed ration (proportion of concentrate 0.51 )

TMR2C $=$ Total mixed ration (proportion of concentrate 0.45 + additional concentrates)

$\mathrm{ng}=$ not given additional concentrate

Differences between treatments were not significant $(\mathrm{P}>0.05)$ for any of the measured parameters

$\mathrm{SEM}=$ standard error of means

feed intake of all cows during different phases, the intake for cows fed TMR2C was one $\mathrm{kg}$ lower $(\mathrm{P}=$ $0.10)$ than for cows fed TMR1 during Phase 2, i.e. lactation days 101-150 (Table 3, Fig. 1a). Average supplies of ME, CP and AAT during different phases were not significantly different between treatments. Development of feed intake of primiparous cows on TMR1 and TMR2C treatments (Fig. 1b) was alike and thus the differences mentioned earlier were due to differences of feed intakes of multiparous cows (Fig. 1c).

Average DM intakes of additional commercial concentrates (TMR2C) were $4.7 \mathrm{~kg}$ for multiparous cows and $3.5 \mathrm{~kg}$ for primiparous cows on days
$1-100$ and $2.5 \mathrm{~kg}$ and $2.0 \mathrm{~kg}$ on days $101-150$, respectively. Thus, the average proportions of concentrates in the TMR2C diet were 0.566 (days 1100), 0.515 (days 101-150) and 0.455 in Phase 3 (Table 3). During the whole experiment, the total average consumption of concentrate per cow was similar for both treatments, $2426 \mathrm{~kg}$ DM (TMR1) and $2414 \mathrm{~kg}$ DM (TMR2C).

Average (all, primiparous and multiparous cows) milk, ECM, protein, fat and lactose yields $\mathrm{kg} \mathrm{d}^{-1}$ and milk composition were not significantly different between diets $(\mathrm{P}>0.05)$ (Table 4). The apparent efficiency of energy utilisation in milk production $\left(\mathrm{k}_{1}\right)$ of all cows was also similar be- 
Vol. 15 (2006): 268-279.

Table 3. Treatment effects on average feed intake of all cows during different phases (1-100, 101-150, 151--224).

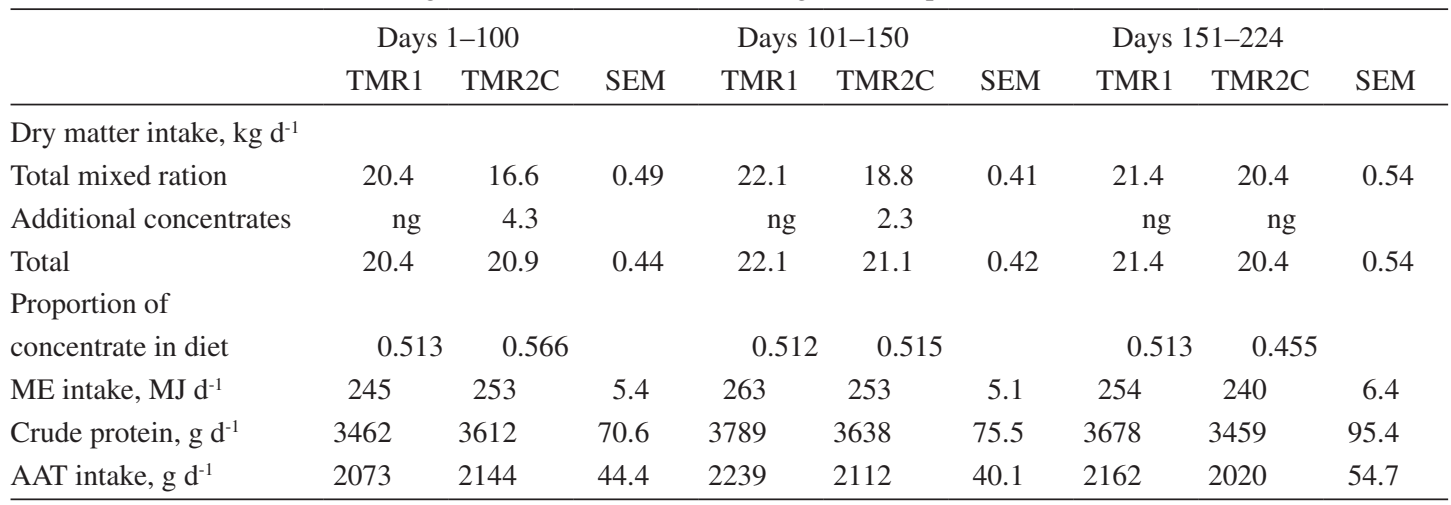

$\mathrm{ng}=$ not given additional concentrate

TMR1 = Total mixed ration (proportion of concentrate 0.51 )

TMR2C $=$ Total mixed ration (proportion of concentrate $0.45+$ additional concentrates)

$\mathrm{ME}=$ Metabolizable energy

AAT $=$ Amino acids absorbed in small intestine

Differences between treatments were not significant $(\mathrm{P}>0.05)$ for any of the measured parameters

$\mathrm{SEM}=$ standard error of means

tween TMR1 and TMR2C (0.63 vs. 0.64). An average $\mathrm{N}$ utilisation of all cows (milk protein yield per protein intake) was $0.30(\mathrm{P}>0.05)$. Figure 2 shows that primiparous cows tended to produce more ECM $(\mathrm{P}=0.08)$ during Phase 2 when additional concentrate was given with TMR2 compared to TMR1 feeding. During the different phases (Table 5), the average ECM yields or yields of milk components of all cows were not significantly different between diets. Energy and amino acid utilisation were similar between TMR 1 and TMR2C in all phases (Table 5).

At parturition, both primiparous and multiparous cows were in optimum condition (BCS slightly above 3 , Fig 3 ). The body condition score decreased for primiparous and multiparous cows during the experiment, but diets did not cause any significant differences $(\mathrm{P}>0.05)$ in BCS development.

\section{Discussion}

The dietary proportion of concentrate consumed in the TMR2C diet was 0.57 during the first 100 days and the daily amount of additional concentrate fed averaged $4.3 \mathrm{~kg}$ DM (all cows). At this level of additional concentrate, cows consumed less TMR2 (3.8 $\mathrm{kg} \mathrm{DM}$ ) compared to intake of TMR1, but the total feed intakes were not different. In most cases, energy supplements decreased silage DM intake, while total DM intake increased (Faverdin et al. 1991, Aston et al. 1995, Agnew et al. 1996). Increases in the proportion of concentrate in the diet has stimulated higher total DM intakes in animals fed total mixed rations (Robinson and McQueen 1997, Friggens et al. 1998). In the present study, total ME intake was very similar between diets and the calculated ME contents ( $\mathrm{MJ} \mathrm{kg}^{-1} \mathrm{DM}$ ) of the diets consumed were 12.01 and 12.11 for TMR1 and TMR2C, respectively. Thus, also ECM and milk component yields were equal between diets.

During Phase 2 (days 101-150 after parturition), the proportion of concentrate in both diets was the same, but total feed intake tended $(\mathrm{P}<$ 0.10 ) to be lower on the TMR2C diet. This showed clearly that decreasing the amount of daily additional concentrate from an average 4.3 to $2.3 \mathrm{~kg}$ DM was too sudden (day 101) since the cows were not able to increase enough their intake of TMR2 to compensate for the difference. This lower total DM intake was not, however, high enough to affect 
Khalili, H. et al. Offering additional concentrates with total mixed rations to dairy cows

Total intake, $\mathrm{kg} \mathrm{DM} \mathrm{d} \mathrm{d}^{-1}$

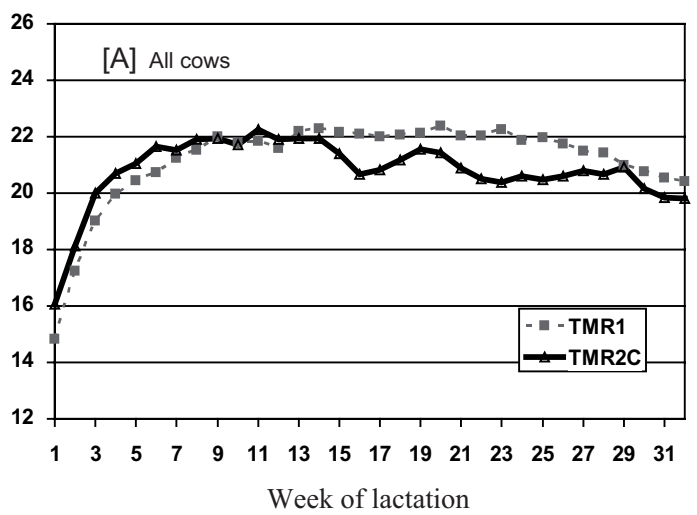

Total intake, $\mathrm{kg} \mathrm{DM} \mathrm{d} \mathrm{d}^{-1}$

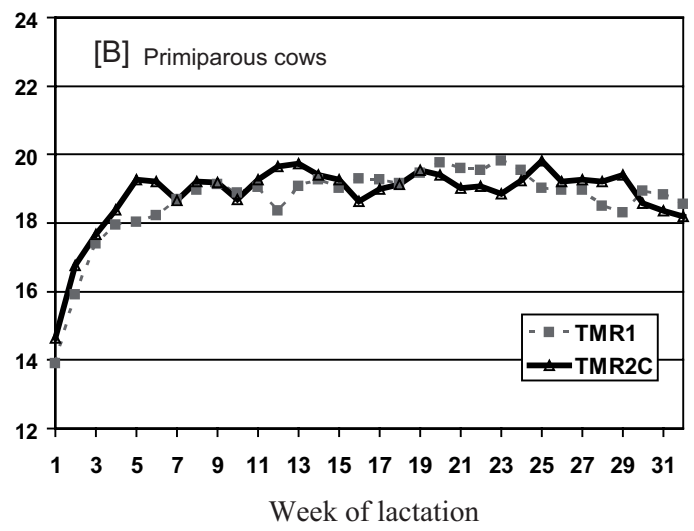

Total intake, $\mathrm{kg} \mathrm{DMd}^{-1}$

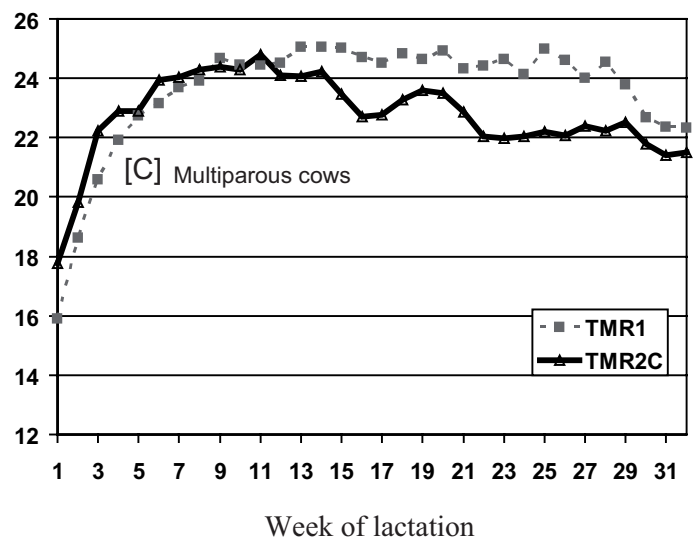

Fig. 1. Mean treatment effects on average total dry matter (DM) intakes on weeks 1-32 of lactation, [A] all cows, [B] primiparous cows and [C] multiparous cows. TMR1 $(-\square-)$, TMR2C $(-\Delta-)$. the ECM and milk component yields of all cows in the TMR2C diet compared to TMR1.

Treatments altered the lactation curves of primiparous cows (see Fig. 2), because the cows on the TMR2C diet had higher milk yields after week 14 of lactation than the cows on TMR1. The ECM yield was in line with higher concentrate intakes on TMR2C than on TMR1 since total DM intakes and body condition scores were quite similar. In contrast, there was a decrease in both the ECM yield and total feed intake but not in body condition score of multiparous cows after week 14 of lactation on TMR2C. Similar negative effects on the feed intake and ECM yield of multiparous cows were noticed when feeding of extra concentrate was terminated (week 21). These examples showed the need to avoid sudden and marked changes in feeding of supplementary concentrates.

There is controversy over feeding strategies of concentrates during early lactation. For example, Østergaard and Gröhn (2000) concluded that in early lactation feeding of concentrates separately from roughages was associated with increased odds of enteritis and ketosis. On the other hand, Yan et al. (1998) fed concentrate within a complete diet or separately from the silage through a computerised feeder system (four $\times 6 \mathrm{~h}$ time windows) and they did not find any significant differences between diets on DM intake, milk production, nutrient digestion or rumen fermentation. In the present study, the concentrate intake of cows on TMR2C diet was divided into several eating periods and thus there should not have been clear differences between treatments in the ruminal $\mathrm{pH}$ (not measured). Ruminal $\mathrm{pH}$ has been reported to alter the ruminal fermentation pattern (Chamberlain et al. 1985), which could affect the milk composition. Here the similar milk fat content might indicate a similar rumen fermentation pattern. Aston et al. (1995) offered multiparous cows silage ad libitum combined with a fixed average amount of concentrate throughout the lactation. They noticed no benefit in milk production from a strategy of giving a greater proportion of concentrate in the ration in early lactation. Recently, Mäntysaari et al. (2004) fed primiparous cows TMR with a fixed 
Vol. 15 (2006): 268-279.

Table 4. Mean treatment effects on average milk production of all, primiparous and multiparous cows.

\begin{tabular}{|c|c|c|c|c|c|c|c|c|c|}
\hline & \multicolumn{2}{|c|}{ All cows } & \multicolumn{3}{|c|}{ Primiparous cows } & \multicolumn{4}{|c|}{ Multiparous cows } \\
\hline & TMR1 & TMR2C & SEM & TMR1 & TMR2C & SEM & TMR1 & TMR2C & SEM \\
\hline Milk, $\mathrm{kg} \mathrm{d}^{-1}$ & 31.8 & 32.2 & 1.07 & 26.3 & 28.3 & 1.00 & 36.6 & 36.1 & 1.58 \\
\hline $\mathrm{ECM}, \mathrm{kg} \mathrm{d}^{-1}$ & 32.9 & 32.9 & 0.97 & 27.9 & 29.3 & 0.83 & 37.8 & 36.5 & 1.54 \\
\hline Fat, $\mathrm{kg} \mathrm{d}^{-1}$ & 1.31 & 1.33 & 0.038 & 1.11 & 1.19 & 0.032 & 1.52 & 1.47 & 0.061 \\
\hline Protein, $\mathrm{kg} \mathrm{d}^{-1}$ & 1.07 & 1.08 & 0.028 & 0.93 & 0.95 & 0.028 & 1.21 & 1.21 & 0.040 \\
\hline Lactose, $\mathrm{kg} \mathrm{d}^{-1}$ & 1.56 & 1.59 & 0.052 & 1.35 & 1.39 & 0.062 & 1.75 & 1.77 & 0.074 \\
\hline \multicolumn{10}{|l|}{ Milk composition } \\
\hline Fat, $\mathrm{g} \mathrm{kg}^{-1}$ & 41.7 & 41.9 & 0.66 & 42.1 & 42.5 & 0.74 & 41.4 & 41.4 & 1.00 \\
\hline Protein, $\mathrm{g} \mathrm{kg}^{-1}$ & 34.2 & 34.1 & 0.45 & 35.7 & 33.8 & 0.75 & 32.9 & 34.1 & 0.53 \\
\hline Lactose, $\mathrm{g} \mathrm{kg}^{-1}$ & 48.9 & 49.6 & 0.32 & 50.2 & 50.1 & 0.24 & 47.7 & 48.9 & 0.51 \\
\hline Urea, $\mathrm{mg} \mathrm{l}^{-1}$ & 225 & 228 & 10.7 & 195 & 223 & 14.0 & 250 & 231 & 13.7 \\
\hline $\mathrm{ECM}, \mathrm{kg}(\mathrm{MJ} \mathrm{ME})^{-1}$ & 0.130 & 0.133 & 0.0040 & 0.127 & 0.130 & 0.0039 & 0.134 & 0.135 & 0.0057 \\
\hline Protein yield, g (g AAT) $)^{-1}$ & 0.505 & 0.513 & 0.0142 & 0.504 & 0.491 & 0.0172 & 0.507 & 0.533 & 0.0186 \\
\hline Protein yield $\mathrm{kg}(\mathrm{kg} \mathrm{CP})^{-1}$ & 0.300 & 0.302 & 0.0082 & 0.300 & 0.289 & 0.0101 & 0.301 & 0.314 & 0.0107 \\
\hline $\mathrm{k}_{1}$ & 0.625 & 0.636 & 0.0124 & 0.656 & 0.623 & 0.0188 & 0.587 & 0.640 & 0.0157 \\
\hline
\end{tabular}

TMR1 = Total mixed ration (proportion of concentrate 0.51 )

TMR2C $=$ Total mixed ration (proportion of concentrate 0.45 + additional concentrates)

$\mathrm{ECM}=$ Energy corrected milk calculated according to MTT (2004).

$\mathrm{ME}=$ Metabolizable energy

AAT $=$ Amino acids absorbed in small intestine

$\mathrm{CP}=$ crude protein

$\mathrm{k}_{1}=$ milk energy (ME intake-ME for maintenance-ME for live weight change) ${ }^{-1}$

Differences between treatments were not significant $(\mathrm{P}>0.05)$ for any of the measured parameters

$\mathrm{SEM}=$ standard error of means

(0.45) or decreasing $(0.55,0.45$ and 0.35$)$ proportion of concentrate and they reported no differences in ECM yield, milk composition, DM intake or body condition score between diets.

Minor decreases in body condition scores on both strategies indicated little nutrient mobilisation from tissues. Maltz et al. (1992) reported that when cows were fed TMR (about $66 \%$ concentrate), they gained more body weight than cows in an individually supplemented group. In the present study, feeding strategies did not affect the yield of ECM per MJ ME and of milk protein $\mathrm{g}$ ( $\mathrm{g}$ absorbed amino acids $)^{-1}$, and average values of $0.13 \mathrm{~kg} \mathrm{ECM}$ and $0.51 \mathrm{~g}$ protein yield were recorded. Also average $\mathrm{N}$ utilisation in milk production $(0.30)$ was in line with the average efficiency of 0.28 based on several experiments in which cows were fed grass silage and concentrate diets (Huhtanen et al. 2003). Milk urea concentration (mean value for all cows
$227 \mathrm{mg} \mathrm{kg}^{-1}$ ) was in agreement with good $\mathrm{N}$ utilisation since a high milk urea content (above 350 $\mathrm{mg}$ ) has been indicative of a less efficient utilisation of $\mathrm{N}$ and highly increased $\mathrm{N}$ excretion in the urine (Nousiainen 2004). More detailed measurements have indicated that feeding method (separate feeding vs. TMR) had no effect on the quantities of energy and $\mathrm{N}$ excreted in faeces, urine or milk, indicating that the additional energy and $\mathrm{N}$ intake with complete diet was retained within the animal (Agnew et al. 1996). They concluded that the first lactation animals used in their study were partitioning additional nutrients towards weight gain rather than milk production.

The total cumulative amount of concentrates consumed on both concentrate feeding strategies was the same. Increasing the proportion of concentrate in the diet caused similar marginal responses which were $0.51 \mathrm{~kg} \mathrm{ECM} \mathrm{kg}^{-1}$ concentrate DM for 
Khalili, H. et al. Offering additional concentrates with total mixed rations to dairy cows

Table 5. Treatment effects on average milk production of all cows during different phases (days 1-100, 101-150, 151224).

\begin{tabular}{|c|c|c|c|c|c|c|c|c|c|}
\hline & \multicolumn{2}{|c|}{ Days 1-100 } & \multirow[b]{2}{*}{ SEM } & \multicolumn{2}{|c|}{ Days 101-150 } & \multicolumn{4}{|c|}{ Days 151-224 } \\
\hline & TMR1 & TMR2C & & TMR1 & TMR2C & SEM & TMR1 & TMR2C & SEM \\
\hline Milk, $\mathrm{kg} \mathrm{d}^{-1}$ & 32.9 & 34.7 & 1.26 & 33.0 & 32.5 & 1.02 & 29.6 & 28.1 & 1.28 \\
\hline $\mathrm{ECM}, \mathrm{kg} \mathrm{d}^{-1}$ & 34.3 & 35.0 & 1.15 & 33.6 & 33.1 & 0.96 & 30.7 & 29.7 & 1.23 \\
\hline Fat, $\mathrm{kg} \mathrm{d}^{-1}$ & 1.37 & 1.42 & 0.050 & 1.32 & 1.31 & 0.048 & 1.22 & 1.23 & 0.062 \\
\hline Protein, $\mathrm{kg} \mathrm{d}^{-1}$ & 1.09 & 1.16 & 0.038 & 1.10 & 1.07 & 0.028 & 1.05 & 0.99 & 0.042 \\
\hline Lactose, $\mathrm{kg} \mathrm{d}^{-1}$ & 1.62 & 1.73 & 0.060 & 1.60 & 1.57 & 0.048 & 1.44 & 1.36 & 0.069 \\
\hline \multicolumn{10}{|l|}{ Milk composition } \\
\hline Fat, $\mathrm{g} \mathrm{kg}^{-1}$ & 42.5 & 40.8 & 0.82 & 40.8 & 40.8 & 0.96 & 41.7 & 43.7 & 1.06 \\
\hline Protein, $\mathrm{g} \mathrm{k}^{\mathrm{g}-1}$ & 33.6 & 33.8 & 0.47 & 33.9 & 33.6 & 0.51 & 35.6 & 35.3 & 0.60 \\
\hline Lactose, $\mathrm{g} \mathrm{kg}^{-1}$ & 49.3 & 50.1 & 0.35 & 48.8 & 49.7 & 0.33 & 48.4 & 48.5 & 0.40 \\
\hline Urea, $\mathrm{mg} \mathrm{l}^{-1}$ & 215 & 215 & 12.1 & 240 & 234 & 13.7 & 228 & 235 & 12.0 \\
\hline $\mathrm{ECM}, \mathrm{kg}(\mathrm{MJ} \mathrm{ME})^{-1}$ & 0.139 & 0.140 & 0.005 & 0.126 & 0.131 & 0.003 & 0.122 & 0.124 & 0.004 \\
\hline Protein yield, g (g AAT) $)^{-1}$ & 0.528 & 0.540 & 0.017 & 0.493 & 0.507 & 0.012 & 0.492 & 0.486 & 0.017 \\
\hline Protein yield, kg (kg CP) $)^{-1}$ & 0.316 & 0.320 & 0.010 & 0.291 & 0.298 & 0.007 & 0.289 & 0.284 & 0.010 \\
\hline
\end{tabular}

TMR1 $=$ Total mixed ration $($ proportion of concentrate 0.51$)$

TMR2C $=$ Total mixed ration (proportion of concentrate $0.45+$ additional concentrates)

$\mathrm{ECM}=$ Energy corrected milk calculated according to Tuori et al. (2000)

$\mathrm{ME}=$ Metabolizable energy

AAT $=$ Amino acids absorbed in small intestine

$\mathrm{CP}=$ Crude protein

Differences between treatments were not significant $(\mathrm{P}>0.05)$ for any of the measured parameters

$\mathrm{SEM}=$ standard error of means

TMR2C diet during Phase 1 (days 1-100) and 0.59 $\mathrm{kg}$ ECM for TMR1 diet during last phase (days 151-224). When total consumption of concentrates was equal, cows produced similar amounts of ECM on TMR1 and TRM2C diets. These results could be applied on farm level also so that TMR2C can be used as a feeding strategy in a free stall where cows are milked within an automated milking system. Prescott et al. (1998) concluded that motivation to access a concentrate feed reward could be used to attract cows into the milking robot provided that the cows were not able to satisfy their motivation elsewhere. They also reported that motivation to be milked apparently was weak and is therefore unlikely to be a significantly important incentive for attracting cows to an automatic milking system.

In conclusion, the results showed that both TMR1 alone (proportion of concentrate 0.51 ) and
TMR2 (proportion of concentrate 0.45 ) with additional concentrate supplement resulted in similar overall performances. Concerning primiparous cows, the results tended to indicate that offering additional concentrate during lactation days 101150 was beneficial to these cows and, consequently, improved milk production. Decreasing on lactation day 101 the amount of concentrate offered to multiparous cows from 6.5 to $3 \mathrm{~kg}$ caused a decrease in feed intake and ECM production. Thus, too abrupt and marked changes in concentrate allowance of high yielding cows are not recommended.

Acknowledgements. The authors wish to thank the staff of Animal Production Research and Jokioinen Experimental Farm for their assistance. The financial support of the Finnish Ministry of Agriculture and Forestry and Suomen Rehu Ltd is gratefully acknowledged. 
Vol. 15 (2006): 268-279.

Energy corrected milk, $\mathrm{kg} \mathrm{d}^{-1}$

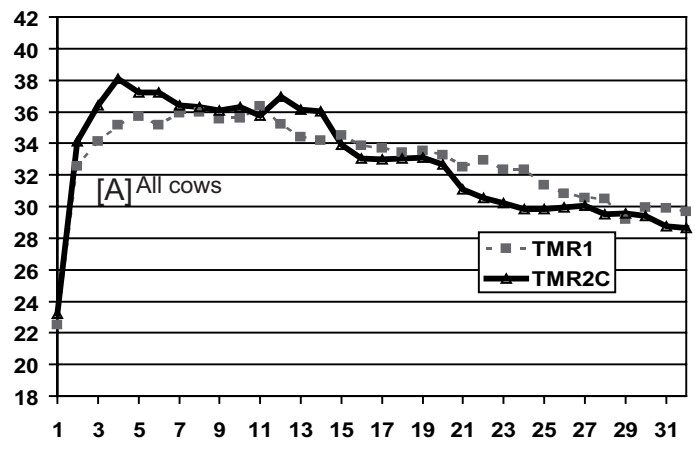

Week of lactation

Energy corrected milk, $\mathrm{kg} \mathrm{d}^{-1}$

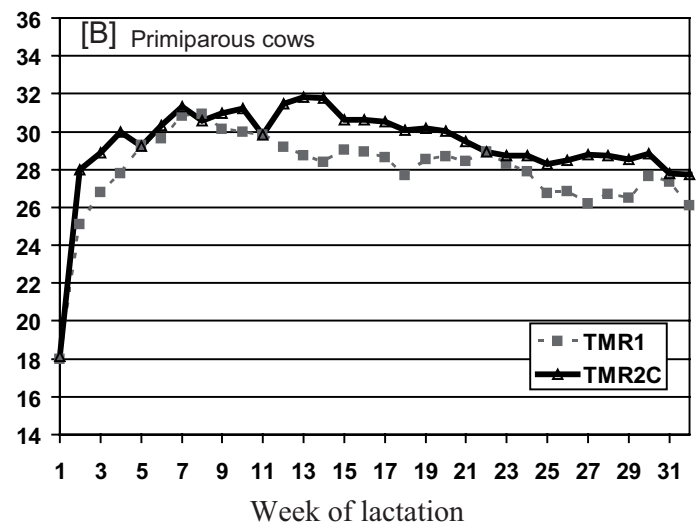

Energy corrected milk, $\mathrm{kg} \mathrm{d}^{-1}$

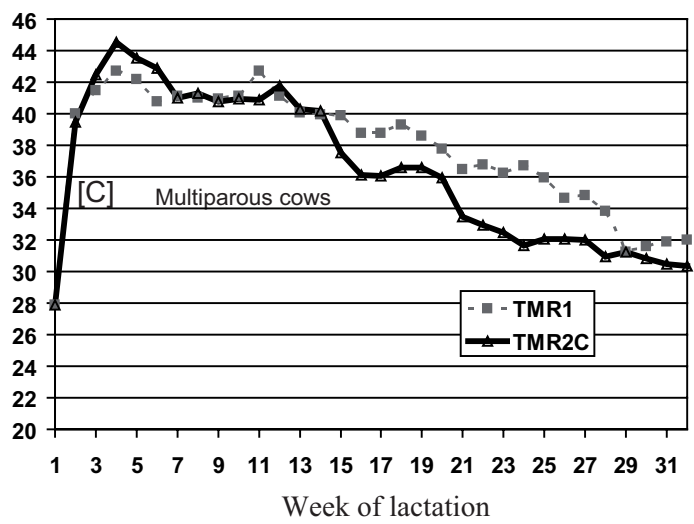

Fig. 2. Mean treatment effects on average yields of energy corrected milk (ECM) on weeks 1-32 of lactation, [A] all cows, [B] primiparous cows and [C] multiparous cows. TMR1 (- - $)$, TMR2C (- $\left.-\Delta^{-}\right)$.
Body condition score

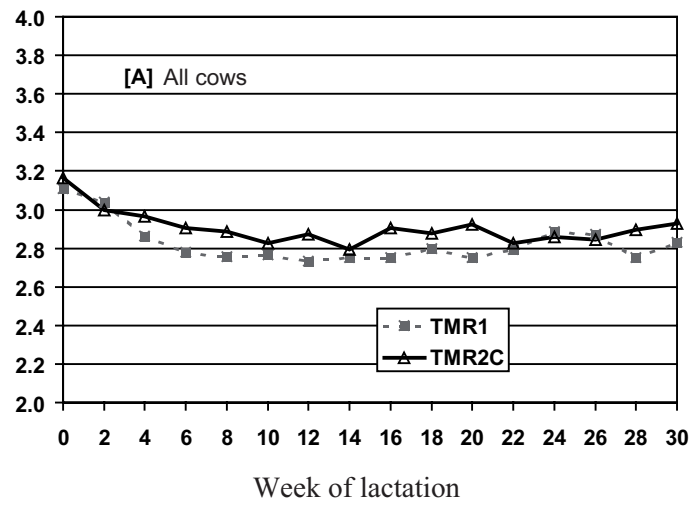

Body condition score

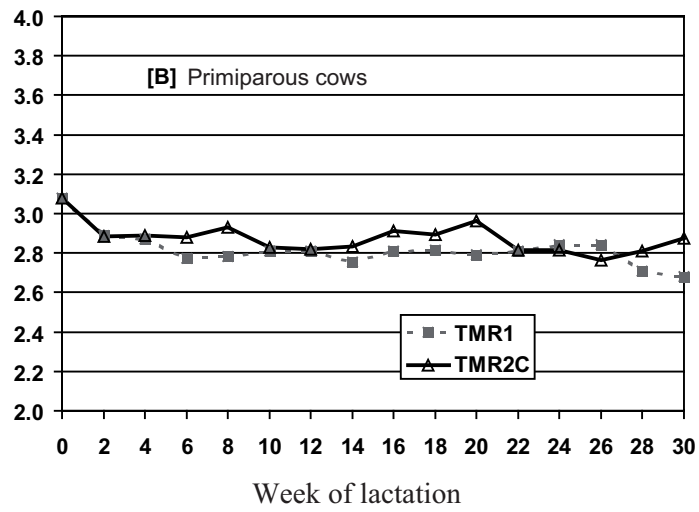

Body condition score

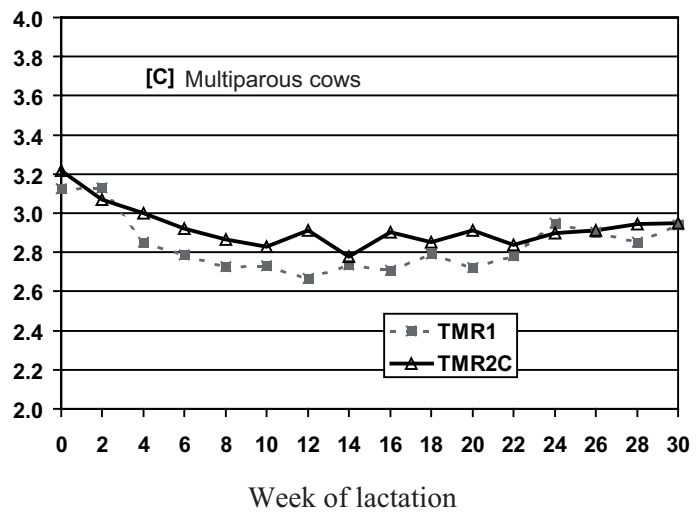

Fig. 3. Mean treatment effects on average body condition scores on weeks 1-30 of lactation, [A] all cows, [B] primiparous cows and $[\mathrm{C}]$ multiparous cows. TMR1 (-口- ), $\operatorname{TMR} 2 \mathrm{C}(-\Delta-)$. 


\section{References}

Agnew, K.W., Mayne, C.S. \& Doherty, J.G. 1996. An examination of the effect of method and level of concentrate feeding on milk production in dairy cows offered a grass silage-based diet. Animal Science 63: 21-31.

Ahvenjärvi, S., Vanhatalo, A., Huhtanen, P. \& Varvikko, T. 2000. Determination of reticulo-rumen and wholestomach digestion in lactating cows by omasal canal or duodenal sampling. British Journal of Nutrition 83: 6777.

AOAC 1990. Official methods of analysis. Association of Official Analytical Chemists, Inc., Arlinton, VA. 1298 p. ISBN 0-935584-42-0.

Aston, K., Sutton, J.D. \& Fisher, W.J. 1995. Milk production from grass silage diets: strategies for concentrate allocation. Animal Science 61: 465-480.

Chamberlain, D.G., Thomas, P.C., Wilson, W., Newbold, C. J. \& MacDonald, J.C. 1985. The effects of carbohydrate supplements on ruminal concentrations of ammonia in animals given diets of grass silage. Journal of Agricultural Science, Cambridge 104: 331-340.

Faverdin, P., Dulphy, J.P., Coulon, J.B., Vérité, R., Garel, J. P., Rouel, J. \& Marquis, B. 1991. Substitution of roughage by concentrates for dairy cows. Livestock Production Science 27: 137-156.

Friggens, N.C., Emmans, G.C., Kyriazakis, I., Oldham, J.D. \& Lewis, M. 1998. Feed intake relative to stage of lactation for dairy cows consuming total mixed diets with a high or low ratio of concentrate to forage. Journal of Dairy Science 81: 2228-2239.

Huhtanen, P., Khalili, H., Nousiainen, J.I., Rinne, M., Jaakkola, S., Heikkilä, T. \& Nousiainen, J. 2002. Prediction of the relative intake potential of grass silage by dairy cows. Livestock Production Science 73: 111-130.

Huhtanen, P., Nousianen, J.I. \& Khalili, H. 2003. Efficiency of $\mathrm{N}$ utilisation in milk production. In: Niemeläinen, O. \& Topi-Hulmi, M. (eds.). Proceedings of the 22nd NJF Congress 'Nordic Agriculture in Global Perspective', 1-4 July 2003, Turku, Finland. Jokioinen: MTT Agrifood Research Finland, NJF. p. 1-5.

Huida, L., Väätäinen, H. \& Lampila, M. 1986. Comparison of dry matter contents in grass silages as determined by oven drying and gas chromatographic water analysis. Annales Agriculturae Fenniae 25: 215-230.

Littell, R.C., Milligen, G.A., Stroup, W.W. \& Wolfinger, R.D. 1996. SAS system for mixed models. 1st ed. SAS Institute Inc. Cary, NC. 633 p.

Lowman B.G., Scott N.A. \& Sommerville S.H. 1976. Condition scoring of cattle. East Scotland College for Agriculture, Bulletin No. 6. 31 p.

McCleary, B.V., Solah, V. \& Gibson, T.S. 1994. Quantitative measurement of total starch in cereal flours and products. Journal of Cereal Science 20: 51-58.

McCullough, H. 1967. The determination of ammonia in whole blood by direct colorimetric method. Clinica Chimica Acta 17: 297-304.

Maltz, E., Devir, S., Kroll, O., Zur, B., Spahr, S.L. \& Shanks, R.D. 1992. Comparative responses of lactating cows to total mixed rations or computerized individual concentrate feeding. Journal of Dairy Science 75: 1588-1603.

Mäntysaari, P., Huhtanen, P., Nousiainen, J. \& Virkki, M. 2004. The effect of concentrate crude protein and feeding strategy of total mixed ration on performance of primiparous dairy cows. Livestock Production Science 85: 223-233.

MTT 2004. Rehutaulukot ja ruokintasuositukset (Feed tables and feeding recommendations). Updated 30 June 2004. Cited 1 June 2005. Available on the Internet: http://www.agronet.fi/rehutaulukot/.

Niemi, J. \& Ahlstedt, J. 2003. Finnish agriculture and rural industries 2003. MTT Agrifood Research Finland, Economic Research, Publications 103a. 94 p.

Nousiainen, J. 2004. Development of tools for the nutritional management of dairy cows on silage-based diets. Academic dissertation. University of Helsinki, Department of Animal Science, publications 72. ISBN 952-10-08652 (PDF). Helsinki 2004. Yliopistopaino. 61 p.

Nousiainen, J., Rinne, M., Hellämäki, M. \& Huhtanen, P. 2003. Prediction of the digestibility of the primary growth of grass silages harvested at different stages of maturity from chemical composition and pepsin-cellulase solubility. Animal Feed Science and Technology 103: 97-111.

NRC 1989. Nutrient requirements of dairy cattle. 6th rev. ed. National Research Council. National Academy Press, Washington, D.C. 157 p.

Østergaard, S. \& Gröhn, Y.T. 2000. Concentrate feeding, dry-matter intake, and metabolic disorders in Danish dairy cows. Livestock Production Science 65: 107118.

Prescott, B.B., Mottram, T.T. \& Webster, A.J.F. 1998. Relative motivations of dairy cows to be milked or fed in a Y-maze and an automatic milking system. Applied Animal Behaviour Science 57: 23-33.

Robinson, P.H. \& McQueen, R.E. 1997. Influence of level of concentrate allocation and fermentability of forage fiber on chewing behaviour and production of dairy cows. Journal of Dairy Science 80: 681-691.

Yan, T., Patterson, D.C. \& Gordon F.J. 1998. The effect of two methods of feeding the concentrate supplement to dairy cows of high genetic merit. Animal Science 67: 395-403.

Yrjänen, S., Kaustell., K., Kangasniemi, R., Sariola, J. \& Khalili, H. 2003. Effects of concentrate feeding strategy on the performance of dairy cows housed in a free stall barn. Livestock Production Science 81: 173-181. 


\title{
SELOSTUS
}

\section{Pelkän seosrehun tai laimeamman seoksen ja väkirehulisän vaikutukset lypsylehmien maidontuotantoon}

\author{
Hannele Khalili, Päivi Mäntysaari, Juha Sariola ja Reima Kangasniemi \\ Maa- ja elintarviketalouden tutkimuskeskus
}

Suurissa tuotantoyksiköissä pihatto-olosuhteissa lypsylehmät ruokitaan yleisesti seosrehulla, mutta pihatoissa on usein käytössä myös väkirehukioskit. Ulkomaisia tai kotimaisia koetuloksia kioskiruokinnan yhdistämisestä seosrehuruokintaan ei kuitenkaan ole käytettävissä. Tämän tutkimuksen tarkoituksena oli selvittää väkirehukioskin merkitystä seosrehuruokinnan täydentäjänä pihatossa.

Tutkimuksessa verrattiin toisiinsa pelkkää seosrehuruokintaa ja ruokintaa, jossa laimeampaa perusseosta täydennettiin lypsykauden alussa väkirehuautomaatista saatavalla lisäväkirehuannoksella. Kokeessa oli kaikkiaan 39 ayrshirelehmää. Puolet lehmistä sai ainoastaan seosrehua, jossa väkirehun osuus kuiva-aineesta oli $51 \%$, ja puolet sai laimeampaa seosta, jossa väkirehun osuus kuiva-aineesta oli $45 \%$. Laimeampaa seosta saaneet lehmät saivat lisäksi lypsykauden alussa väkirehua kioskista. Päivittäinen lisäväkirehuannos oli laktaatiopäivinä 1-100 useammin poikineilla $6,5 \mathrm{~kg}$ ja ensikoilla 5,5 kg. Laktaatiopäivinä 101-150 oli kioskiväkirehuannos useammin poikineilla $3,0 \mathrm{~kg}$ ja ensikoilla $2,5 \mathrm{~kg}$.
Loppulypsykaudella (yli 150 päivää poikimisesta) lisäväkirehua ei annettu.

Kioskilisä ei vaikuttanut keskimääräiseen kuiva-aineen syöntiin tai ravintoaineiden saantiin. Tarkasteltaessa syöntejä jaksoittain havaittiin, että ensimmäisen 100 lypsypäivän aikana syönti kehittyi samaa vauhtia molemmissa koeryhmissä. Sen sijaan seuraavan 50 päivän aikana ainoastaan seosrehua saaneet lehmät söivät enemmän kuin lehmät, jotka saivat lisärehua kioskeista. Tulos on kuitenkin vain suuntaa antava. Kun lisärehuryhmän kioskiannosta pudotettiin 100 ja 150 lypsypäivien jälkeen, niin lehmät eivät pystyneet lisäämään seoksen syöntiä vastaavaa määrää, ja näin kokonaissyönnit jäivät alhaisemmiksi kuin ainoastaan seosrehua saaneella ryhmällä. Koekauden keskimääräisissä maito-, energiakorjattumaito-, rasva- ja valkuaistuotoksissa ei ollut ryhmien välillä eroa. Myöskään lehmien kunnon kehityksessä ei ollut eroa ruokintojen välillä. Johtopäätöksenä voidaan todeta, että molemmat ruokintastrategiat soveltuivat hyvin lehmien ruokintaan. 